\title{
Young Adult Literature in the English Language Arts Classroom: A Survey of Middle and Secondary Teachers' Beliefs about YAL
}

\author{
ANN MARIE SMITH \\ University of TeXas of The Permian Basin
}

LISA HAZLETT

UNIVERSITY OF SOUTH DAKOTA

\section{SEAN LENNON}

VALDOSTA STATE UNIVERSITY

The goal of this survey study was to discover the reasons for the use or nonuse of young adult literature in the classroom. This study revealed that YAL has gained in popularity with middle school teachers. New information, presented from qualitative data analysis on open-ended survey responses, adds to previous research on how teachers use YAL in secondary classrooms.

Hayn, Kaplan \& Nolen (2011) recommend that young adult literature (YAL) researchers shift their focus from its classroom uses, critiques, and other anecdotal descriptions to observations and analyses about how young adult literature assists students' reading and learning. However, if YAL is not regularly taught or read in schools, researchers may be unable to study pedagogical trends. From observing classrooms in our local schools, the researchers learned that YAL was definitely being taught in secondary schools. To learn how and if YAL is taught across the nation, the authors constructed the following research question: "How do teachers use YAL in classrooms?" The authors were interested in learning how school environment and demographics also inform teachers' use or nonuse of YAL. 
This survey research demonstrates how a sample of teachers respond to questions about how (or if) YAL is taught. Although YAL is taught by some teachers, the reasons for not teaching YAL vary from interpretations of Common Core Standards to an emphasis on the classics. These results contribute to knowledge of how and why YAL is taught in schools, as well as why teachers choose not to-or are unable to-teach YAL.

Although young adults read literature written for adults, we define YAL as literature written specifically for adolescents in grades 6-12 (Hazlett, Johnson, \& Hayn, 2009). The question of how often YAL is taught in middle and high school classrooms and methods used for its teaching arose. Scholars and practitioners have long recommended various methods for young adult literature's classroom use to engage students and enhance reading comprehension (Groenke \& Scherff, 2010; Guthrie \& Humenick, 2004; Guthrie, Rueda, Gambrell \& Morrison, 2009). However, research on how young adult literature is implemented in secondary classrooms is limited (Hayn, Kaplan \& Nolen, 2011).

Using the instrument developed by Hazlett, Johnson, \& Hayn (2009), the goal of our survey was to discover the reasons for the use or nonuse of YAL in the classroom and to identify any changes since their findings. Our survey, seven years after the Hazlett, Johnson \& Hayn (2009) study, revealed that YAL has gained in popularity with middle school teachers. However, YAL appears to disappear from the curriculum after grade nine, according to survey results. Although preferable to believe this gain resulted from greater educator awareness of YAL literature and its scholarship, this cannot be documented by our sample alone. Our survey yielded some similarities in quantitative data to the 2009 study, but our survey was unique in that it included open-ended questions (unlike the original) that allowed for additional insight into reasons why some teachers choose or do not choose to incorporate YAL into their curriculum.

\section{THE YAL SURVEY}

The questionnaire (see Appendix A) was distributed online through Survey Monkey to National Council of Teachers of English (NCTE) organization members with respondents randomly selected from NCTE's master membership list (Creswell, 2003). Hazlett, Johnson \& Hayn, in their original study, indicated that they mailed paper surveys; Survey Monkey and other related software were not yet in use or commonly available. However, for the authors of this study, such 
technology was available and utilized, allowing for a more randomized study of respondents across the U.S. It also allowed for a blind study as the authors were not aware of who returned the surveys (we could have checked the ISPs) but overall the sample was anonymous, a plus in reducing potential bias in interpreting results (Creswell, 2003). In our study, four hundred and nineteen emails were sent with sixty-seven surveys completed, a return rate of sixteen percent. This return rate was within expected norms of similar teacher surveys using "cold calling” or anonymous solicitations through district-assigned emails (Hazlett, Johnson \& Hayn, 2009; Lennon, Smith \& Byford, 2014). This population is difficult to reach within targeted return rates and may need to be identified at lower expectations (Groves, et al., 2004).

\section{STUDY LIMITATIONS}

After reviewing the finished surveys, there is no indication of relevancy and/or topic salience bias although it should be noted that such limitations do exist and would be difficult to ascertain through the online format of the survey methodology. In this regard, the authors note the limitations of the study and applied only descriptive statistics as inferences about a larger population could be flawed (Creswell, 2003).

\section{SURVEY RESPONDENTS}

Although the sampling size was slightly larger, our respondents were similar to Hazlett, Johnson \& Hayn (2009) and reflect national data. According to NCES, 81.9\% of ELA educators were Caucasian females, and 57\% of ELA educators have over ten years of experience as of 2011-2012 (National Center for Education Statistics.) Sixty-two of our respondents were white females, having between six and twenty-five years of ELA teaching experience, which echoes national statistics. The majority of our respondents taught high school level classes with about ten percent teaching college and 26\% teaching middle school (See Table 1). Most of our respondents (96\%) had six or more years of teaching experience. Less experienced teachers might be wary of responding to a survey or may not have the time to respond (See Table 1). 


\section{TABLE 1}

Demographics of Respondents

\begin{tabular}{|c|c|c|c|c|c|c|c|c|c|c|}
\hline & Race/Ethnicity & $\mathrm{N}$ & Age & $\mathrm{N}$ & $\begin{array}{l}\text { Years } \\
\text { Classroom } \\
\text { Experience }\end{array}$ & $\mathrm{N}$ & Degrees & $\mathrm{N}$ & $\begin{array}{l}\text { Studen } \\
\text { grade } \\
\text { level } \\
\text { taught }\end{array}$ & $\mathrm{N}$ \\
\hline $\mathrm{N}=67$ & $\begin{array}{l}\text { Black } \\
\text { Hispanic } \\
\text { White } \\
\text { Other }\end{array}$ & $\begin{array}{l}2 \\
1 \\
62 \\
2\end{array}$ & $\begin{array}{l}2130 \\
3140 \\
41-50 \\
51-\end{array}$ & $\begin{array}{l}4 \\
13 \\
29 \\
20\end{array}$ & $\begin{array}{l}5 \text { or less } \\
6-15 \\
16-25 \\
26+\end{array}$ & $\begin{array}{l}3 \\
25 \\
25 \\
14\end{array}$ & $\begin{array}{l}\text { Bachelors } \\
\text { Master's } \\
\text { Doctoral } \\
\text { Hours + }\end{array}$ & $\begin{array}{l}33 \\
53 \\
8 \\
21\end{array}$ & $\begin{array}{l}6^{\text {th }} \\
7^{\text {th }} \\
8^{\text {th }} \\
9^{\text {th }} \\
10^{\text {th }} \\
11^{\text {th }} \\
12^{\text {th }} \\
13^{\text {th }}\end{array}$ & $\begin{array}{l}4 \\
8 \\
5 \\
18 \\
20 \\
32 \\
36 \\
7\end{array}$ \\
\hline
\end{tabular}

$52 \%$ of our respondents had not taken any YAL classes, with $25 \%$ completing one class in YAL (See Table 2). This is surprising, as pre-service ELA education majors' coursework requirements for certification is consistent throughout the US, with YAL being a required course. Even if undergraduates do not take a YAL course, they must take hours in English methods. Another possibility is that not all English/language arts teachers are trained in university English education programs. The instrument did not include specific questions about teacher training, so reasons for the lack of YAL coursework are impossible to infer. The responses to the YAL courses as helpful for the teachers were concentrated in the responses 2 (almost never) and 3 (sometimes). This is somewhat distressing for teacher educators who design YAL courses to prepare future teachers. However, this question did not allow for responders to specify where and under what conditions they acquired information about YAL, and this was not an open-ended question, a limitation noted later in this article. 
TABLE 2

Young Adult Literature courses taken and impact

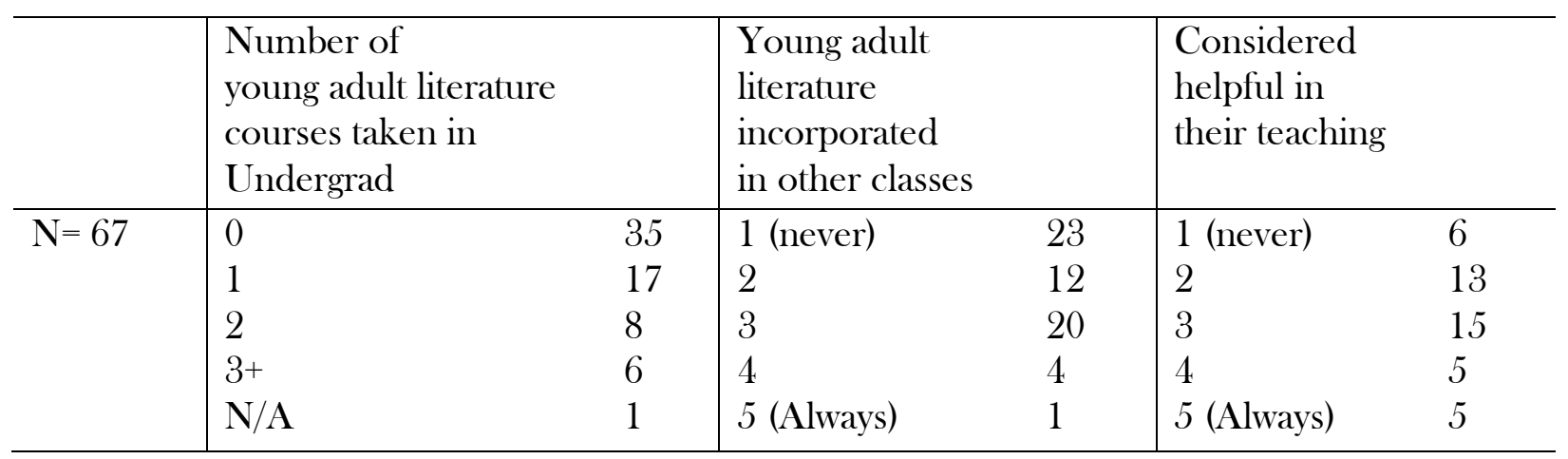

Surprisingly, the percentage of teachers who teach in schools with 900 plus students was larger than we expected (See Table 3). After subtracting the number of teachers who taught college, those who taught at schools with 900 or more students were 40 percent of our respondents for this question. Class size was alarming, but not surprising due to the tendency toward overcrowding in public schools. In a recent NCTE position statement on class size and teacher load, the suggested teacher load was under 100 students (Why Class Size Matters), 69\% of the respondents had class sizes of twenty-one or above. Sixteen percent claimed class sizes of twenty-nine or above. Class sizes of twenty-nine or above would most likely limit students' academic success in spite of teachers' best efforts (Why Class Size Matters, 2014).

\section{TABle 3}

Classes and School Comparisons

\begin{tabular}{l|ll|ll|l|l}
\multicolumn{2}{c}{} & \multicolumn{2}{c|}{$\begin{array}{c}\text { Student grade } \\
\text { level }\end{array}$} & \multicolumn{2}{c|}{$\begin{array}{c}\text { Student } \\
\text { population }\end{array}$} & \multicolumn{2}{c}{$\begin{array}{c}\text { Average class } \\
\text { size }\end{array}$} \\
\hline $\mathrm{N}=67$ & 6 th & 4 & $100-300$ & 5 & $<12$ & 2 \\
& 7 th & 8 & $301-600$ & 10 & $12-20$ & 19 \\
& 8 th & 5 & $601-900$ & 14 & $21-28$ & 35 \\
& 9 th & 18 & $900+$ & 38 & $29-35$ & 11 \\
& 10 th & 20 & & & $36+$ & 0 \\
& 11 th & 32 & & & & \\
& 12 th & 36 & & & & \\
\hline
\end{tabular}




\begin{tabular}{l|ll|l|l|l}
\hline & 13 th & 7 & & & \\
\hline
\end{tabular}

Conference participation was similar to that of the 2009 study with twelve presenting at NCTE, with attendance (not presenting) approximately $10 \%$ higher than reported previously. Our results are included in Table 4. Similar results occurred at the state affiliate level, although 2009 survey respondents were more active in presenting at the state level than our sample. Convention attendance is expensive, with varying levels of funding available (if at all) for educators, including post-secondary ones. Moreover, many public school teachers must use accrued leave for attendance, not always available or convenient. When asked state affiliate attendees if YAL was included, 52\% answered “don't know” in our study (See Table 4).

TABLE 4

Professional Conferences

\begin{tabular}{|c|c|c|c|c|c|c|c|c|c|c|c|c|}
\hline & \multicolumn{2}{|c|}{$\begin{array}{c}\text { Attended } \\
\text { an ALAN } \\
\text { convention } \\
\text { or } \\
\text { conference }\end{array}$} & \multicolumn{2}{|c|}{$\begin{array}{c}\text { Presented } \\
\text { at an } \\
\text { ALAN } \\
\text { convention } \\
\text { or } \\
\text { conference }\end{array}$} & \multicolumn{2}{|c|}{$\begin{array}{l}\text { Held an } \\
\text { elected } \\
\text { office or } \\
\text { leadership } \\
\text { position at } \\
\text { ALAN }\end{array}$} & \multicolumn{2}{|c|}{$\begin{array}{c}\text { Attended an } \\
\text { NCTE } \\
\text { conventions } \\
\text { or conference }\end{array}$} & \multicolumn{2}{|c|}{$\begin{array}{l}\text { Presented at } \\
\text { an NCTE } \\
\text { conventions } \\
\text { or } \\
\text { conference }\end{array}$} & \multicolumn{2}{|c|}{$\begin{array}{l}\text { Held an } \\
\text { elected } \\
\text { office or } \\
\text { leadership } \\
\text { position at } \\
\text { NCTE }\end{array}$} \\
\hline \multirow[t]{5}{*}{$\mathrm{N}=67$} & 0 & 52 & () & 24 & () & 24 & 0 & 25 & 0 & 32 & 0 & 39 \\
\hline & $1-5$ & 10 & $1-5$ & 1 & $1-5$ & 2 & $1-5$ & 31 & $1-5$ & 9 & $1-5$ & 3 \\
\hline & $6-10$ & () & $6-10$ & 0 & $6-10$ & 0 & $6-10$ & 3 & $6-10$ & 2 & $6-10$ & 1 \\
\hline & $11-15$ & 0 & $11-15$ & 0 & $11-15$ & 0 & $11-15$ & 0 & $11-15$ & () & $11-15$ & 0 \\
\hline & $16^{+}$ & 1 & $16^{+}$ & 0 & $16^{+}$ & 0 & $16+$ & 3 & $16^{+}$ & 1 & $16^{+}$ & 1 \\
\hline
\end{tabular}

\section{RESPONDENTS' OPINIONS OF YAL AND CLASSROOM USE}

Table 5 includes responses to survey questions about familiarity of YAL and incorporation of YAL into English language arts classrooms. The sum of our responses seems to suggest that student teacher awareness of YAL is increasing. Our study's results included 11\% for the bottom end (No) and $24 \%$ for the top end (Yes). We also had a choice for "N/A", chosen by fifty percent of the respondents. Our results suggest that at least half of our respondents are not aware of student 
teachers' knowledge of YAL or lack thereof. For those that are aware, it appears from our sample that student teachers' knowledge about YAL may have improved since 2009.

TABle 5

YAL and Classroom Use

\begin{tabular}{|c|c|c|c|c|c|c|c|c|c|c|}
\hline $\begin{array}{l}\mathrm{N}= \\
67\end{array}$ & \multicolumn{2}{|c|}{$\begin{array}{l}\text { Young adult } \\
\text { literature is } \\
\text { incorporated } \\
\text { into my } \\
\text { school's } \\
\text { curriculum }\end{array}$} & \multicolumn{2}{|c|}{$\begin{array}{l}\text { Young adult } \\
\text { literature is } \\
\text { not } \\
\text { incorporated } \\
\text { into my } \\
\text { school's } \\
\text { curriculum, } \\
\text { but I } \\
\text { incorporate it } \\
\text { into my } \\
\text { teaching }\end{array}$} & \multicolumn{2}{|c|}{$\begin{array}{c}\text { We have } \\
\text { young adult } \\
\text { authors speak } \\
\text { at our school, } \\
\text { and/or attend } \\
\text { events }\end{array}$} & \multicolumn{2}{|c|}{$\begin{array}{l}\text { My student } \\
\text { teachers are } \\
\text { familiar with } \\
\text { young adult } \\
\text { literature }\end{array}$} & \multicolumn{2}{|c|}{$\begin{array}{l}\text { My } \\
\text { colleagues are } \\
\text { familiar with } \\
\text { CURRENT } \\
\text { young adult } \\
\text { literature }\end{array}$} \\
\hline & 1 (never) & 4 & 1 (never) & 12 & 1 (never) & 32 & 1 (never) & 1 & 1 (never) & \\
\hline & 2 & 22 & 2 & 12 & 2 & 18 & 2 & 6 & 2 & 12 \\
\hline & 3 & 16 & 3 & 11 & 3 & 4 & 3 & 5 & 3 & 22 \\
\hline & 4 & 8 & 4 & 9 & 4 & 6 & 4 & 10 & 4 & 21 \\
\hline & 5 (always) & 11 & 5 (always) & 8 & 5 (always) & 1 & $\begin{array}{l}5 \text { (always) } \\
\text { N/A }\end{array}$ & $\begin{array}{l}6 \\
34\end{array}$ & & \\
\hline
\end{tabular}


TABLE 5, continued

\begin{tabular}{|c|c|c|c|c|c|c|c|c|c|c|}
\hline \multirow[t]{6}{*}{$\mathrm{N}=67$} & \multicolumn{2}{|c|}{$\begin{array}{l}\text { I have been } \\
\text { discouraged } \\
\text { from using } \\
\text { young adult } \\
\text { literature in my } \\
\text { teaching by } \\
\text { colleagues }\end{array}$} & \multicolumn{2}{|c|}{$\begin{array}{c}\text { I have been } \\
\text { discouraged from } \\
\text { using adult } \\
\text { literature in my } \\
\text { teaching by } \\
\text { administrators }\end{array}$} & \multicolumn{2}{|c|}{$\begin{array}{l}\text { I have been } \\
\text { discouraged } \\
\text { from using } \\
\text { young adult } \\
\text { literature in my } \\
\text { teaching by } \\
\text { parents }\end{array}$} & \multicolumn{2}{|c|}{$\begin{array}{c}\text { I wish my } \\
\text { colleagues, } \\
\text { administrators, } \\
\text { and/or parents, } \\
\text { would be more } \\
\text { accepting of young } \\
\text { adult literature }\end{array}$} & \multicolumn{2}{|c|}{$\begin{array}{l}\text { I refrain from } \\
\text { using some } \\
\text { young adult } \\
\text { literature due to } \\
\text { censorship } \\
\text { concerns }\end{array}$} \\
\hline & 1 (never) & 42 & 1 (never & 45 & 1 (never & 46 & 1 (never) & & 1 (never) & 27 \\
\hline & 2 & 12 & 2 & 8 & 2 & 14 & 2 & 14 & 2 & 15 \\
\hline & 3 & 3 & 3 & 3 & 3 & 1 & 3 & 21 & 3 & 9 \\
\hline & 4 & 3 & 4 & 3 & 4 & 0 & & 11 & & 7 \\
\hline & 5 (always) & 1 & 5 (always) & 1 & 5 (always) & 0 & 5 (always) & & 5 (always) & 3 \\
\hline
\end{tabular}

\section{ANALYZING COMMENTS FROM OPEN-ENDED QUESTIONS}

This survey section contained Likert Scale and open-ended questions about YAL. Likert Scale responses are summarized in Table 6 . The Likert scaled questions used a five-point scale and always went in the same direction with the number three being "neutral" or "not sure" (Creswell, 2003). Items 35-37 state: I have been discouraged from using adult literature in my teaching by colleagues, administrators and parents, respectively. Most responses fell between response items 3 and 5 (with 5 being Always and 1 being Never), meaning that the majority of our respondents have NOT been discouraged from using YAL by colleagues or administrators. $88 \%$ responded with a one or two for questions 35 and 36; $98 \%$ responded with a 1 or 2 for question number 37 about parents' influence, which suggests that parents do not seem to have much influence over teachers' choices about YAL. Of course, the data may change if the survey respondents were primarily beginning teachers. Experienced teachers know how to defend their choices and/or have department/administrator support for YAL choices.

Question 38 on the survey states, "I refrain from using some adolescent literature due to censorship concerns." 31\% responded with a 3,4 and 5 (with Likert scale choices of 1 being never 
and 5 being always), suggesting some concern for censorship. This response spread could also suggest that teachers participate in a process of self-censorship to avoid possible repercussions from administrators or parents.

\section{TABLE 6}

\section{Factors Affecting Teachers' Use of YAL}

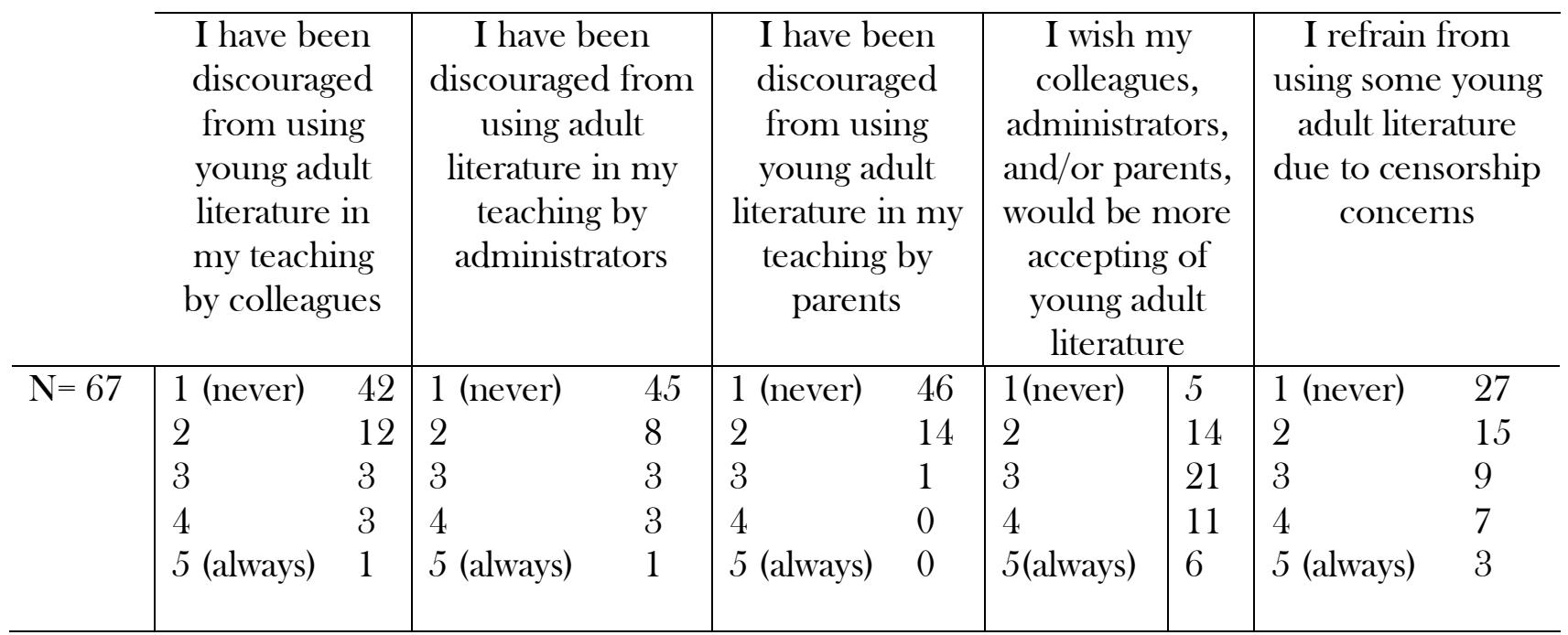

\section{USE OF YA LITERATURE IN THE CLASSROOM}

Although $48 \%$ of respondents stated that their classroom use of YAL was productive, $21 \%$ disagreed. It would have been helpful to provide space for comments for this question to invoke more information. Regarding using YAL, only one respondent indicated its use in-eleventh and twelfth grade. Choice of literature selection may be limited for some teachers who work at schools in which a committee decides on required literature. Or, some schools may not supply teachers with YAL or other literature due to financial constraints. However, ten respondents commented on a variety of uses within grades seven through nine, supporting the information received from informal interviews with university students and local teachers about YAL use in the middle grades.

Suggested uses outside of class included independent reading, summer reading programs, and literacy support classes. Beliefs about the quality and complexity of YAL when compared to the classics may explain why YAL is relegated to activities outside of the standard English language 
arts classroom. One respondent wrote, "We are not allowed to use literature in the classroom. We USED to use literature, but we were forced into a Basal program.” Research on implementations of scripted programs, basal programs or other required curriculum is needed to substantiate if schools are moving toward basils or anthologies in place of YAL (DeWitz \& Jones, 2012). Although anthologies are often commonly used as classroom texts, the convenience of anthologies and basals did not seem to be the reason our respondents cited most often for not using YAL. Only one respondent mentioned being forced to convert to a scripted, reading program.

Comments for question 40 did not seem to fit one specific category or theme. For example, one respondent wrote that Tears of the Tiger and Speak were used in ninth grade while another respondent commented that YAL was used in grades 9, 10 and 11. One teacher commented, "Students often relate well to these books which motivates them to read. Teaching theme, character development, and conflict. . . along with researching current issues can stem from YAL novels." One respondent indicated that academic support classes used YAL, and "English One classes offer YAL selections for students to read and use for participation in book clubs." The perception that YAL is just for low level readers is implied; however, book clubs often include readers with a variety of reading abilities and interests (Polleck, 2016).

Discovering how YAL was used in teaching resulted in some in-depth responses with several emerging themes. Two respondents stated that as they taught advanced placement courses, YAL was not applicable because they chose to teach from the traditional literary canon. One teacher commented, "I use it [YAL] very little since the focus of my AP course is nonfiction." One criticism of the Common Core Standards is that nonfiction does not need to completely replace literature (Hayn, Kaplan, Nolen, \& Olvey, 2016). Of course, other teachers and scholars have written that YAL is high quality, and more engaging and relevant to students than works from the traditional canon (Crowe, 2001; Rakow, 1991).

Those YA literature titles mentioned repeatedly included Speak (Anderson, 2011), The Hunger Games (Collins, 2010), Tears of a Tiger (Draper, 1996), Ellen Foster (Gibbons, 2012), Harry Potter series (Rowling, 2015), and Flipped (Van Draanen, 2003). Titles educators' used to teach canonical works included Lady Macbeth's Daughter (Klein, 2009) with MacBeth (Shakespeare, 2003), and Hungers Games (Collins, 2010) with 1984 (Orwell, 1961).

Analyzing trends in the use of young adult literature in secondary ELA classrooms needs qualitative attention. Researchers and practitioners would benefit from authentic portraits of how 
and why YA literature is taught, or in the case of some respondents, eliminated from the curriculum. Presenting a practical picture of what may be occurring with YA literature in schools became one the purposes of the questions in the qualitative section of this survey.

Question 48 stated (Describe how your use of YAL has changed from when you began teaching to the present, if applicable) and 49 (Have increased standards, assessments, accountability, etc. affected the use of YAL in your classroom? If so, explain how). Responses to these questions were compared and analyzed for themes, with three emerging from the responses. (Theme 1: Less time for novels because of state standards and required tests, Theme 2: Change to teaching AP or high school required use of adult literature (or literature with higher lexile levels) and Theme 3 : Increased use of YA literature because of knowledge and experiences with YAL. The most positive theme, theme three summed up respondents' enthusiasm for teaching YAL in their classrooms. Some believed that they have increased their use of YAL because they have acquired knowledge of YAL, keep up with recent YAL publications, and have learned new teaching methods and activities. Examples of this theme and the other themes are discussed in the following section.

Theme 1. Less time for novels because of state standards and tests. Eight respondents commented that because of increased requirements of state standards, time didn't allow for teaching whole novels. One respondent explained, "Our department is required to plan collaboratively, and while I would like to read more YA lit, I do not have the resources or the time to fit much into my curriculum for the semester." Implicit in all three responses was the desire for more choice regarding text selection and how many could be taught within a set time frame. Teachers critiqued the time needed for state standards and standardized test preparation. Depending on the state, curricula are limited to specific topics and texts that all teachers must include. With required content to cover, time for in-class reading and discussion of YAL is limited or unavailable.

Theme 2. Change to teaching AP or high school required use of adult literature (or literature with higher lexile levels). Seven respondents explained that the amount of YAL was reduced when they began teaching advanced placement or high school classes. One respondent explained, "When I taught grades 6-9, my literature focus was on YA literature. In teaching AP, however, we concentrate more on adult canonical works." Five out of the seven respondents stated YAL was not as rigorous or advanced as needed for use. One respondent indicated that YAL had a low "lexile level.” The Common Core emphasizes the importance of text complexity; however, the formula provided for test complexity goes beyond lexile level. (Alsup, 2013; Mesmer, 2008; National 
Governors Association Center for Best Practices [NGA Center] \& Council of Chief State School Officers [CSSO], 2010). It is possible that teachers and administrators are reducing the Common Core requirement of "text complexity" to lexile level scores. Higher lexile levels do not indicate text complexity, and the formula provided by the Common Core does not necessarily capture the nuances of literary quality; however, the Common Core formula requires a more elaborative analysis than lexile level computations (Alsup, 2013; National Governors Association for Best Practices [NGA center] \& Council of Chief State School Officers [CSSO], 2010). If teachers are governed by top down administrators, they may choose to follow the path of least resistance by focusing on classical literature, assuming study of such texts meets the Common Core requirements of complex text.

Theme 3. Increased use of YAL because of knowledge and experiences. The nine respondents who explained reasons for their increased use of YA literature had a master's Degree and at least six years of teaching experience. One respondent explained that including YA literature was part of a gradual process over time: "I started out in a Basal when I began my career. It wasn't getting their interest. I started using literature and the change in the students was amazing. I kept at it, differentiating the novels by levels and ability, but teaching the same skills as well as using the same types of assessments." Three of the respondents mentioned that attending NCTE conventions has continually exposed them to new YAL and methods for teaching.

Contrary to the responses in theme 1, three teachers explained that Common Core State Standards (CCSS), as they interpreted the requirements, supported the use of more YAL. Two of the respondents indicated that the state standards were vague enough that they could use YAL to improve literacy skills. One respondent explained, "I refuse to just do skill drills and have always incorporated as much reading that would appeal to YA as possible in various genres including rap." Another respondent commented: "YA Lit is certainly not on the benchmarks the county gives us, but nevertheless you practice the same comprehension skills etc. when reading YAL.” These teachers have learned what motivates their students through years of experience. Although teacher educators expose teacher candidates to YAL, professional teachers most likely need to find time to keep up with recent YAL. Beyond exposure, perhaps teacher educators need to prepare teacher candidates to explain the reasons for using YAL to improve reading comprehension to their administrators. 
Other teachers may answer differently, especially in lower performing schools, but those are the very students who need YAL to increase engagement (Bull, 2012; Gallagher, 2009; Kelley, Wilson \& Koss, 2012) Tatum (2008) asserts that adolescent readers must be motivated to read both in and out of school in order to improve reading comprehension; YAL increases student enjoyment of reading, encouraging students to become lifelong readers (Ivey \& Johnston, 2013).

One respondent summarized her view on teaching YAL, defending the strength of YA literature to connect students with contemporary social issues:

I take a lot of grief about not teaching 'rigorous' texts. Many of my colleagues

(especially when I was teaching in HS) felt that unless the text was difficult it wasn't worth reading. Take The Circuit, for example. On a lexile level - it's easy. To take that book and compare it to The House on Mango Street or to present day immigration issues - WOW! Who cares about the lexile count? It's a great way to teach contemporary immigration issues while giving students a perspective they have no other way of gaining (typically).

YAL can teach students to take social responsibility (Glasgow, 2001; Stover \& Bach, 2012) as well as teach students to interrogate systems of power and privilege (Glasgow, 2001). YAL has the power to capture students' imaginations and interests. Although YAL does not need to replace canonical literature, much YAL is of high literary quality. Focusing on lexile level as a reason for choosing students' reading materials does not guarantee text complexity.

\section{CONCLUSIONS AND IMPLICATIONS}

Although we believe that YAL does not need defending, it is desired that ELA educators will continue to teach YAL, expounding on its effectiveness in motivating adolescents to read. Explaining how YAL engages adolescents by connecting to their lives and interests is one step toward getting teachers to embrace YAL (Buehler, 2016). Teacher educators emphasize the importance of YAL in teacher preparation classes, and those professors who work with schools should continue to encourage public school teachers to use YAL with their students.

For example, the first author invites local teachers to her English education and YAL classes to share how they use YAL with their students. The first author and colleagues have also planned a workshop on how to incorporate YAL in the content areas for the university STEM academy. 
Showing pre-service teachers how experienced teachers use YAL in the classrooms should be our responsibility as teacher educators.

Teacher educators should continue to expose teacher candidates to YAL, while preparing them to move beyond various limitations placed upon their literature choices. Teacher educators must prepare teacher candidates by explicating methods and language for passing on the understanding that teaching and using young adult literature helps create life-long readers (Santoli \& Wagner, 2004). Although YAL in middle school seems to be prevalent, it needs to also reach secondary school readers. In an age of top-down standards and high stakes testing, it is important that teachers incorporate high-interest YAL into the classroom to engage students in critical literacy through discussion and writing (Garcia, 2013). Administrators and university professors should encourage teachers to attend state and national conferences, such as NCTE and ALAN. Further, University professors can mentor classroom teachers and offer to present with them about teaching strategies for YAL.

In high stakes testing environments, improving literacy comprehension through strategy instruction may dominate. As teacher educators, we understand that we may need to remind teacher candidates about the extant research on how reading YAL can improve students' reading comprehension while addressing students' interests and experiences. Finally, more research is needed on how YAL is actually taught in classrooms. Research and practitioner journals must continue to include articles about professional development effective in helping teachers choose and teach YAL. 


\section{REFERENCES}

Alsup, J. (2013). Teaching literacy in an age of text complexity. Journal of Adolescent and Adult Literacy, 57(3), 181-184.

Anderson, L. (2011). Speak. New York: Square Fish.

Buehler, J. (2016). Teaching Reading with YA Literature. Urbana, IL: NCTE.

Bull, K. (2012). Identifying obstacles and garnering support. In J. Hayn \& J. Kaplan (Eds.), Teaching Young Adult Literature Today (pp 61-77). Lanham, MD: Rowman \& Littlefield.

Collins, S. (2010). The Hunger Games. New York: Scholastic.

Creswell, J. (2003). Research Design: Qualitative, Quantitative, and Mixed Methods Approaches, 2nd ed. Sage: Thousand Oaks, CA.

Crowe, C. (2001). Young adult literature: AP and YA? English Journal, 91(1), 123-128.

Dewitz, P. \& Jones, J. (2012). Using basal readers. The Reading Teacher, 66(5), 391- 400.

Draper, S. (1996). Tears of a Tiger. New York: Simon Pulse.

Gallagher, K. (2009). Readicide. Portland, ME: Stenhouse.

Gibbons, K. (2012). Ellen Foster. Chapel Hill, NC: Algonquin Books.

Glasgow, J. (2001). Teaching social justice through young adult literature. English Journal, 90(6), 54-61.

Groenke, S. \& Scherff, L. (2010). Teaching YA Lit Through Differentiated Instruction. Urbana, IL: NCTE.

Guthrie, J. \& Humenick, N. (2004). Motivating students to read: Evidence for classroom practices that increase reading motivation and achievement. In P. McCarle \& V. Chabra (Eds.), The Voice of Evidence in Reading Research (pp. 329-354). Baltimore: Brookes.

Guthrie, J., Rueda, R., Gambrell, L.B., \& Morrison, D. (2009). Roles of engagement, valuing and identification in reading development of students from diverse backgrounds. In L. Morrow, R. Rueda \& D. Lapp (Eds.), Handbook of Research on Literacy and Diversity (pp.195-215). New York: Guilford Press.

Hayn, J. \& Kaplan, J (Eds) (2012). Teaching Young Adult Literature Today. Lanham, MD: Rowman \& Littlefield. 
Hayn, J., Kaplan, J., \& Nolen, A. (2011). Young adult literature research in the 21st century. Theory Into Practice, 50(3), 176-181.

Hazlett, L. (2012). Updating young adult literature reading lists while retaining quality titles. In J. Hayn \& J. Kaplan (Eds.), Teaching Young Adult Literature Today (pp 155-166). Lanham, MD: Rowman \& Littlefield.

Hazlett, L., Johnson, A. \& Hayn, J. (2009). An almost young adult literature study. The ALAN Review, 37(1). 48-53.

Ivy, G. \& Johnson, P. (2013). Engagement with young adult literature: outcomes and processes. Reading Research Quarterly, 45(3). 255-275.

Kelley, M., Wilson, N. \& Koss, M (2012). Using young adult literature to motivate and engage the disengaged. In J. Hayne \& J. Kaplan (Eds.), Teaching Young Adult Literature Today (pp 79-97). Lanham, MD: Rowman \& Littlefield.

Klein, L. (2009). Lady MacBeth’s Daughter. New York: Bloomsbury USA Children’s.

Mesmer, H. (2008). Tools for matching readers to texts: Research-based practices. New York: Guilford.

National Center for Education Statistics. (2010-2011). Retrieved from https://nces.ed.gov/surveys/sass/tables/sass1112_2013314_t1s_001.asp

National Governor's Center for Best Practices \& Council of Chief State School Officers. (2012). Supplemental information for Appendix A of the Common Core State Standards for English language arts and literacy: New research on text complexity. Washington, DC:

Authors. Retrieved from www.corestandards.org/resources.

Orwell, G. (1961). 1984. New York: Penguin Random House.

Rakow, S. (1991). Young-adult literature for honors students? English Journal, 80(1), 48-51.

Rowling, J (2015). Harry Potter and the Sorcerer's Stone: The Illustrated Edition. New York: Arthur A. Levine Books.

Santoli, S. \& Wagner, M. (2004) Promoting young adult literature: The other "real” literature. American Secondary Education, 33(1), 66-75.

Shakespeare, W. (2003). MacBeth. New York: Simon \& Schuster.

Stover, L. \& Bach, J. (2012). Young adult literature a call to social activism. In J. Hayn \& J. Kaplan (Eds.), Teaching young adult literature today (pp 203-222). Lanham, MD: Rowman \& 
Littlefield. Tatum, A. (2008). Overserved or underserved? A focus on adolescents and texts. English Journal, 98(2), 82-85.

Van Draanen, W. (2003). Flipped. New York: Penguin Random House.

Zusak, M. (2007). The Book Thief. New York: Alfred A. Knopf.

ANN MARIE SMITH is an assistant professor at University of Texas of the Permian Basin where she teaches adolescent literature, English education, and literacy education courses in the College of Education. Her scholarship interests include gender and adolescent literature, critical literacy, and strategies for teaching adolescent literature.

Ann Marie Smith, University of Texas of the Permian Basin, $\underline{\text { smith a@utpb.edu }}$

SEAN LENNON is an associate professor at Valdosta State University where he teaches about critical concepts and practices in education. His scholarship includes traits and practices which illicit critical thinking applications in adolescent and adult learners.

Dr. Sean Lennon, Valdosta State University, smlennon@valdosta.edu

LiSA A. HAZLETT is professor of secondary education at the University of South Dakota. A regular presenter for NCTE and ALAN, she has published over 30 book chapters, brochures, and journal articles, all incorporating the reading and study of adolescent literature. However, her preference and expertise is reviewing; she regularly reviews manuscripts, novels, and textbooks centering on young adult literature for numerous journals and publishing houses.

Dr. Lisa Hazlett, University of South Dakota, Lisa.Hazlett@usd.edu 


\section{APPENDIX A}

Survey Regarding the Use of Young Adult Literature in Secondary English/Language Arts

This survey consists of four sections. For each item, choose the response that most accurately reflects your current situation or practice. Please complete both sides of each sheet.

For the purposes of this survey, the following terminology is utilized:

- $\quad$ Young Adult Literature refers to literature written specifically for adolescents in grades 612

- $\quad$ Young Adult Literature Course refers to a class that focuses solely upon the study and use of young adult literature.

Section One: Check the space applicable to you.

1) Gender:

Male Female

2) Age:

$$
21-30
$$

$31-40$

$41-50$

$51+$

3) Teaching Experience:

$0-5$ years

6-15 years

16-25 years

$26+$ years

4) Education Level: Bachelor's Master's Doctoral Hours beyond highest degree

5) Identification: White Black/African American Hispanic/Latino American Indian or Alaska Native Asian Native Hawaiian or Pacific Islander Disabled [Check all that apply]

6) Number of young adult literature courses taken as part of your undergraduate degree program: 0 0 1 2 $3+$ N/A

7) Number of young adult literature courses taken as part of your graduate degree program, or for graduate credit: 
8) Are you a member of the National Council of Teachers of English [NCTE]?

Yes No unfamiliar with organization

If yes, number of years

9) Are you a member of the Assembly on Literature for Adolescents of the National Council of Teachers of English [ALAN]?

Yes __ No ___ unfamiliar with organization __ if yes, number of years

10) List the professional educational journals you regularly read:

11) How many NCTE conventions and conferences have you attended? [If none, skip to \#14]
0
$1-5$
$6-10$
$11-15$
$15+$

12) Of those NCTE conventions and conferences attended, how many times have you been a presenter?
0

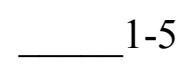
$1-5$
6-10
11-15
$15+$

13) How many NCTE leadership positions (e.g., committee member, elected officer) have you held?
0

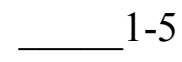
$-5$
6-10
11-15
$15+$

14) How many ALAN workshops have you attended? [If none, skip to \#17]

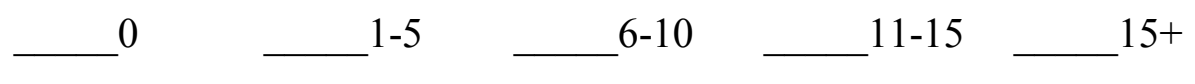

15) Of those ALAN workshops attended, how many times have you been a presenter?

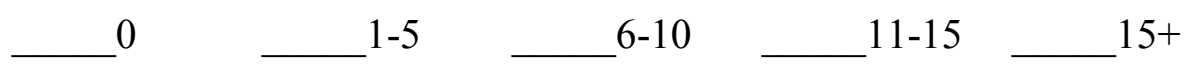


16) How many ALAN leadership positions (e.g., committee member, elected officer) have you held?
0
$1-5$
6-10
$11-15$
$15+$

17) How many state affiliate NCTE conferences have you attended? [If none, skip to \#20]
0
$1-5$
$6-10$
$11-15$
$15+$
$\mathrm{N} / \mathrm{A}$

18) Of those state conferences attended, how many times have you been a presenter?

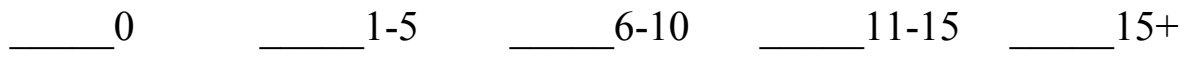

19) How many state affiliate leadership positions (e.g., committee member, elected officer) have you held?

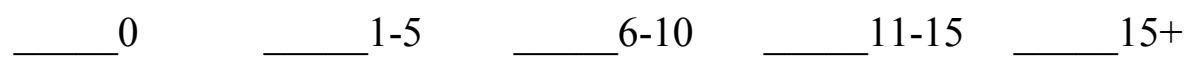

20) Does your state affiliate conference feature sessions about young adult literature?

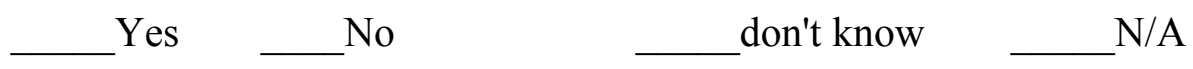

21) Do you regularly attend any professional conference sessions/in-services about young adult literature?
$\underline{Y}$ No N/A

22) English/Language Arts Classes Currently Teaching. For each class you list, indicate the number of sections taught (e.g., 3 sections of $9^{\text {th }}$ Grade English, post-secondary English Methods, Graduate-level British Literature Seminar).

$\underline{\text { Class }}$

Number of Sections 
23) Grade Levels of Your Students: (Check all that apply):

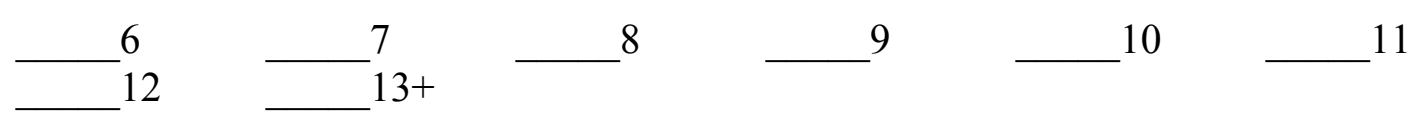

24) Total Student Population in School:

Less than $100 \_100-300 \_301-600 \_601-900 \_$_

25) Your Average Class Size:

Fewer than 12

$12-20$

$21-28$

29-35

$36+$ 
Section Two: For the items below, choose the option that most accurately reflects your current practice. Numerical values represent equal distance on the scale from $1=$ never to $5=$ always.

never always

26) Young adult literature is incorporated into my school's curriculum. $\quad \begin{array}{lllll}2 & 2 & 3 & 4 & 5\end{array}$

27) Young adult literature is not incorporated into my school's curriculum, $\quad \begin{array}{rrrrr}2 & 2 & 4 & 4\end{array}$ but I incorporate it into my teaching.

28) I read young adult literature for pleasure.

29) We have a variety of young adult literature titles available in my school. $\quad \begin{array}{lllll}2 & 3 & 4 & 5\end{array}$

30) We have young adult authors speak at our school, and/or attend events $\quad \begin{array}{lllll}1 & 2 & 3 & 4 & 5\end{array}$ featuring YA authors and their literature.

31) My student teachers are familiar with young adult literature.

32) Young adult literature was incorporated in other [i.e., not a course specific to YA literature] college/university courses I have taken.

33) My colleagues are familiar with current young adult literature.

34) My students read young adult literature.

$\begin{array}{lllll}1 & 2 & 3 & 4 & 5\end{array}$

35) I have been discouraged from using young adult literature in my teaching by colleagues.

36) I have been discouraged from using young adult literature in my teaching by administrators.

37) I have been discouraged from using young adult literature in my teaching by parents.

38) I refrain from using some young adult literature due to censorship concerns.

39) My classroom use of young adult literature has been productive. 
40) Describe how young adult literature is used in your school, if applicable:

41) Describe how young adult literature is used in your teaching, if applicable:

Section Three: For the items below, choose the option that most accurately reflects your current views. Numerical values represent equal distance on the scale from $1=$ never to $5=$ always.

$$
12345
$$

never always

42) My young adult literature coursework was instrumental to my use of $\quad \begin{array}{lllll}1 & 2 & 3 & 4 & 5\end{array}$ NA young adult works in the classroom.

43) My professional experiences (conferences, in-services, etc.) were instrumental to my use of young adult works in the classroom.

44) I feel young adult literature is canonical [i.e., of lasting quality] and should $1 \quad 2 \quad 3 \quad 4 \quad 5$ be taught/used in middle and high school classes.

45) I feel young adult literature is canonical, but should be taught/used only $\quad \begin{array}{lllll}1 & 2 & 3 & 4 & 5\end{array}$ in the middle grades.

46) I feel young adult literature is best used with lower level students, reluctant readers, or free reading. 
47) I wish my colleagues, administrators, and/or parents, would be more $\quad \begin{array}{lllll}1 & 2 & 3 & 4 & 5\end{array}$ accepting of young adult literature.

48) Describe why and how your use of young adult literature has changed from when you began teaching to the present, if applicable:

49) Have increased standards, assessment, accountability, No Child Left Behind et al. affected the use of young adult literature in your classroom/school? If so, explain how:

Section Four: For the items below, choose the option that most accurately reflects your current interests. Numerical values represent equal distance on the scale from $1=$ never to $5=$ always.

12345

never always

50) I am interested in using young adult literature more frequently in my $\begin{array}{lllll}1 & 2 & 3 & 4 & 5\end{array}$ classroom.

51) I am interested in professionally reviewing curricular materials/novels $\quad \begin{array}{lllll}1 & 2 & 3 & 4 & 5\end{array}$ relating to young adult literature.

52) I am interested in becoming professionally active regarding young adult $1 \begin{array}{lllll}1 & 2 & 3 & 4 & 5\end{array}$ literature.

53) State any additional comments you have regarding the use of young adult literature in English/language arts classes at the secondary level: 